\title{
Different segments different survival for T1NO non-small cell lung cancer: should we change our paradigm in patients with superior segment tumors?
}

\author{
Fabrizio Minervini ${ }^{1 \wedge}$, Marco Scarci $^{2} \wedge$ \\ ${ }^{1}$ Department of Thoracic Surgery, Cantonal Hospital Lucerne, Lucerne, Switzerland; ${ }^{2}$ Department of Thoracic Surgery, San Gerardo Hospital, \\ Monza, Italy \\ Correspondence to: Fabrizio Minervini. Department of Thoracic Surgery, Cantonal Hospital Lucerne, Lucerne, Switzerland. \\ Email: fabriziominervini@hotmail.com. \\ Comment on: Jones GD, Caso R, Choe G, et al. Intentional Segmentectomy for Clinical T1 N0 Non-small Cell Lung Cancer: Survival Differs by \\ Segment. Ann Thorac Surg 2021;111:1028-35.
}

Submitted Dec 16, 2020. Accepted for publication Jan 29, 2021.

doi: 10.21037/jtd-20-3528

View this article at: http://dx.doi.org/10.21037/jtd-20-3528

The optimal management of early stage lung cancer is still a matter of discussion among thoracic surgeons. Many studies have already compared disease free survival (DFS) and overall survival (OS) between lobectomy and segmentectomy (1-3). Nowadays, the general consensus is that anatomical sublobar resections are considered equivalent to lobectomy for patients with tumors $<2 \mathrm{~cm}$ even if the lung function is not impaired (4-6). The parenchyma sparing resulting from a segmentectomy could preserve vital lung in case of a further resection in the context of the emerging trend of multifocal adenocarcinomas.

Furthermore, the optimal lymph node resection for early stage non-small cell lung cancers (NSCLC) remained controversial for many years with several trials showing that patients with lobe specific lymph node dissection had lower perioperative morbidities with similar survival when compared with the patients who underwent systematic nodal resection $(7,8)$. The rationale of performing a radical mediastinal node dissection results from observation that basal segment tumors have an increased incidence of positive infracarinal nodes, whereas superior segment tumors often metastasize directly to the upper mediastinum (9).
We read with acute interest the retrospective study of Dr. Jones and colleagues from Memorial Sloan Kettering Cancer Center published in the Annals of Thoracic Surgery.

The authors included 416 patients who underwent intentional segmentectomy for T1N0M0 NSCLC and assessed whether OS and DSF are related to the resected segment.

Even if the 5 years OS was $73.1 \%$ (95\% CI, 67.9-78.7\%) in the entire population (comparable with data from the literature reporting a 5 years OS between 58 and 93\%), the authors found that a superior segmentectomy on the right side is associated with worse OS, DFS and aggressive tumor biology. The same conclusions were drawn by Handa and his colleagues from Japan who reported in a retrospective analysis that segment 6 tumors have a poor OS (hazard ratio $3.33,95 \% \mathrm{CI}, 1.22$ to $13.5, \mathrm{P}=0.010$ ), DFS (hazard ratio $2.90,95 \% \mathrm{CI}, 1.20$ to $7.00, \mathrm{P}=0.008$ ) with more pathological lymph nodes than basal segment group ( $15 \%$ versus $5.4 \%, \mathrm{P}=0.080$ ) (10). A recent article compared outcomes after superior segmentectomy versus lower lobectomy reporting similar 5-year overall, disease free and locoregional-recurrence-free survival rates. Even if the laterality was not analyzed, Dolan observed similar

^ ORCID: Fabrizio Minervini, 0000-0003-3595-7307; Marco Scarci, 0000-0002-4459-7721. 
5 years OS (56.9\%) and DFS (67\%) (11) after a superior segmentectomy.

Besides some limitations of the study (retrospective, single center study), Jones and his group highlight an important but still unanswered topic: should we approach T1N0M0 superior segment tumor in a different manner?

Maybe we have to be more aggressive with this cohort of patients performing an intentional lobectomy (if the lung function allows it) with a radical mediastinal lymphadenectomy given that superior segment tumors often metastasize in the upper mediastinum?

The influence of a segmentectomy on the patient prognosis is still debated and, in the light of the data indicating different survival depending on the resected segment, the tumor location should be taken in account as risk factor.

Further studies, preferably randomized controlled trials, are needed to clarify the therapeutic surgical strategies in patients with superior segment early stage NSCLC.

\section{Acknowledgments}

Funding: None.

\section{Footnote}

Provenance and Peer Review: This article was commissioned by the editorial office, Fournal of Thoracic Disease. The article has undergone external peer review.

Conflicts of Interest: Both authors have completed the ICMJE uniform disclosure form (available at http://dx.doi. org/10.21037/jtd-20-3528). MS serves as an unpaid editorial board member of Fournal of Thoracic Disease from Mar 2020 to Feb 2022. The other author has no conflicts of interest to declare.

Ethical Statement: The authors are accountable for all aspects of the work in ensuring that questions related to the accuracy or integrity of any part of the work are appropriately investigated and resolved.

Open Access Statement: This is an Open Access article distributed in accordance with the Creative Commons Attribution-NonCommercial-NoDerivs 4.0 International License (CC BY-NC-ND 4.0), which permits the noncommercial replication and distribution of the article with the strict proviso that no changes or edits are made and the original work is properly cited (including links to both the formal publication through the relevant DOI and the license). See: https://creativecommons.org/licenses/by-nc-nd/4.0/.

\section{References}

1. Bedetti B, Bertolaccini L, Rocco R, et al. Segmentectomy versus lobectomy for stage I non-small cell lung cancer: a systematic review and meta-analysis. J Thorac Dis 2017;9:1615-23.

2. Divisi D, De Vico A, Zaccagna G, et al. Lobectomy versus sublobar resection in patients with non-small cell lung cancer: a systematic review. J Thorac Dis 2020;12:3357-62.

3. Cao C, Chandrakumar D, Gupta S, et al. Could less be more?-A systematic review and meta-analysis of sublobar resections versus lobectomy for non-small cell lung cancer according to patient selection. Lung Cancer 2015;89:121-32.

4. Sihoe AD, Van Schil P. Non-small cell lung cancer: when to offer sublobar resection. Lung Cancer 2014;86:115-20.

5. Okada M, Yoshikawa K, Hatta T, et al. Is segmentectomy with lymph node assessment an alternative to lobectomy for non-small cell lung cancer of $2 \mathrm{~cm}$ or smaller? Ann Thorac Surg 2001;71:956-60; discussion 961.

6. Chan EG, Chan PG, Mazur SN, et al. Outcomes with segmentectomy versus lobectomy in patients with clinical T1cN0M0 non-small cell lung cancer. J Thorac Cardiovasc Surg 2020. [Epub ahead of print]. doi: 10.1016/ j.jtcvs.2020.03.041.

7. Okada M, Sakamoto T, Yuki T, et al. Selective mediastinal lymphadenectomy for clinico-surgical stage I non-small cell lung cancer. Ann Thorac Surg 2006;81:1028-32.

8. Darling GE, Allen MS, Decker PA, et al. Randomized trial of mediastinal lymph node sampling versus complete lymphadenectomy during pulmonary resection in the patient with $\mathrm{N} 0$ or $\mathrm{N} 1$ (less than hilar) non-small cell carcinoma: results of the American College of Surgery Oncology Group Z0030 Trial. J Thorac Cardiovasc Surg 2011;141:662-70.

9. Watanabe S, Suzuki K, Asamura H. Superior and Basal Segment Lung Cancers in the Lower Lobe Have Different Lymph Node Metastatic Pathways and Prognosis. Ann Thorac Surg 2008; 85:1026-31.

10. Handa Y, Tsutani Y, Tsubokawa N, et al. Clinical Prognosis of Superior Versus Basal Segment Stage I Non-Small Cell Lung Cancer. Ann Thorac Surg 2017;104:1896-901. 
11. Dolan DP, White A, Mazzola E, et al. Outcomes of superior segmentectomy versus lower lobectomy for superior segment Stage I non-small-cell lung cancer are equivalent: An analysis of 196 patients at a single, high volume institution. J Surg Oncol 2021;123:570-8.

Cite this article as: Minervini F, Scarci M. Different segments different survival for T1N0 non-small cell lung cancer: should we change our paradigm in patients with superior segment tumors? J Thorac Dis 2021;13(3):1303-1305. doi: 10.21037/jtd20-3528 